\title{
RESPONSE OF SOME BARLEY CULTIVARS TO ORGANIC MANURING AND FOLIAR APPLICATION OF THE MICRONUTRIENTS MIXTURE FERTILAN 10 UNDER NEW RECLAIMED SANDY SOIL CONDITIONS.
}

\author{
A.B. Gaballah * and S.A.E. Mowafy ${ }^{* *}$ \\ *Plant Production Department. (Agronomy), Institute of Efficient Productivity, \\ Zagazig University, Egypt. \\ ${ }^{* *}$ Agron. Dept. Fac. of Agric. Zagazig University, Egypt.
}

\section{ABSTRACT}

Two field experiments were conducted at a private farm at El-Salhia region, Sharkia Governorate, Egypt during 2004/2005 and 2005/2006 seasons to study the response of three barley cultivars viz. Giza 123, Giza 124 and Giza 125 to fertilization with three levels from farmyard manure (30, 35 and $40 \mathrm{~m}^{3} / \mathrm{fad}$.) and foliar spray with Fertilan 10 (containing micronutrients mixture) under sandy soil conditions. A split-split plot design with three replicates was used in both seasons.

The results revealed that, barley cultivars differed significantly where Giza 124 produced the highest grain and straw yields/fad. and the lowest grain protein content. However, Giza 125 recorded the highest grain protein content and the highest harvest index.

Foliar spray with Fertilan 10 had favourable significant effect on most studied traits. Grain yield/fad. was increased significantly by $14.54 \%$ over the two seasons due to this treatment.

The increase of farmyard manure rate up to $40 \mathrm{~m}^{3} / \mathrm{fad}$. produced significant increases in grain and straw yields/fad. and most of their attributes. These increases were at for with those produced by the addition of $35 \mathrm{~m}^{3} / \mathrm{fad}$.

No significant interaction effect could be detected between each two of the factors under study on grain yield/fad. or any of its attributes.

The results indicated that grain yield/fad. was positively and highly significantly correlated with all studied traits including number of spikes $/ \mathrm{m}^{2}$, number of grains/spike, weight of grains/spike and 1000-grain weight.

Results cleared that the highest yield could be obtained from sowing Giza 124 barely $c v$. and addition of $35 \mathrm{~m} 3$ FYM with the foliar application of Firtlan 10 , under sandy soil conditions of El-Salhia region, Sharkia Govern orate.

Key words : Barley cultivars, organic manuring and foliar application.

\section{INTRODUCATION}

In Egypt, barley is the main winter crop in the North western coast and North Sinai were it is rain fed and as well under sprinkler irrigation in the newly reclaimed lands. It is used mainly for feeding animals and for bread making, either alone or 
mixed with wheat. Also, it is used for malting in the brewing industry. Most of barley is grown in marginal lands which suffer from adverse conditions such as poor fertility levels. As most of the areas in the newly reclaimed lands are sandy soils, organic manuring and micronutrients fertilization are considered among the most important cultural practices for increasing barley productivity. Many investigators concluded that these cultural practices increased yields of barley cultivars and its components in addition to its quality.

Several workers reported that barley cultivars showed significant differences in yield and yield attributes (Noaman et al., 1995; Gomaa, 1997; El-Hindi et al., 1998; El-Bawab, 1999; Abdel-Hamid and Mohamed, 2000; El-Bawab et al., 2003 and Abd Alla, Moha, 2004). However, Jha et al., 1981; Noworolnik and Pecio, 1989 and Abdel-Hamid et al., 2001 stated insignificant differences between cultivars regarding grain yield and grain protein content.

Soil application of micronutrients to alkaline soils is partially useless due to the fixation of most of these elements in the soil or because of leaching in the drainage water (Reuther, 1957). Mahmoud et al.(1987) found that foliar spray with $0.3 \% \mathrm{ZnSO}$ enhanced significantly number of spikes and grain yield of barley variety CC89.

El-Sayed and Abdel-Hadi, (1991) found that grain yield of barley grown on calcareous soil was increased by $38 \%, 36 \%, 34 \%$ and $9 \%$ over the check treatment by spraying the plants with $\mathrm{Zn}, \mathrm{Mn}, \mathrm{Fe}$ and mixture of $\mathrm{Zn}+\mathrm{Mn}+\mathrm{Fe}$, respectively. Also, Sanjay and Singh, 2004 reported that grain and straw yields were increased significantly with the soil application of $\mathrm{Zn}$ at the rate of $5.0 \mathrm{~kg} \mathrm{Zn} / \mathrm{ha}$. Yield components like effective tillers, ear length, number of grains per ear and test weight were increased significantly due to the application of $5.0 \mathrm{~kg} \mathrm{Zn} / \mathrm{ha}$. compared to lower levels.

The response of barley plants to the increase of organic manure application was studied by many workers. Sharma et al.,(2001) found that grain and straw yields obtained with $75 \mathrm{kgN} / \mathrm{ha}$. alone was at par with that obtained with $60 \mathrm{kgN} / \mathrm{ha}$ along with 10 tons of farmyard manure/ha. El-Toukhy and Abd-Alla, (2002) grew Acacia saligna with both barley and ryegrass under three levels of organic manure $(0,20$ and $40 \mathrm{~m}^{3} / \mathrm{fad}$.). they mentioned that application of $40 \mathrm{~m}^{3} / \mathrm{fad}$. organic manure gave significant increase of fresh and dry yields. Madlain Salib et al.(2002) reported that addition $7.5 \mathrm{~m}^{3}$ farmyard manure (FYM)/fad. was the best treatment for barley plants regarding grain, straw yields, harvest index and 1000-grain weight. Addition of organic manure increased significantly grain yield/ha. compared with treatments without organic manuring (Kismanyoky, 2005 and Berecz et al., 2005).

This investigation aimed to study the response of some barley cultivars to fertilization with organic manure and foliar micronutrients application under new reclaimed sandy soils. 


\section{MATERIALS AND METHODS}

Two field experiments were conducted at a private farm at El-Salhia region, Sharkia Governorate, Egypt during 2004/2005 and 2005/2006 seasons to study the responses of three barley cultivars viz. Giza 123, Giza 124 and Giza 125 to fertilization with three levels from farmyard manure $\left(30,35\right.$ and $40 \mathrm{~m}^{3} / \mathrm{fad}$.) and foliar spray with Fertilan 10 which is a mixture of only micronutrients $(3.5 \% \mathrm{Fe}$, $3.25 \% \mathrm{Mn}, 2.75 \% \mathrm{Zn}, 0.025 \% \mathrm{Cu}, 0.25 \% \mathrm{~B}$, > $0.1 \% \mathrm{Mo}$ ) in addition to cobalt (> $0.1 \%$ ) and Nickel (>0.1\%). The soil of the experimental site is sandy in texture, it had an average $\mathrm{pH}$ value 8.09. and available $\mathrm{N}, \mathrm{P}$ and $\mathrm{K}$ of $11.32,3.74$ and $91.5 \mathrm{ppm}$, respectively (average over the two seasons for the upper $25 \mathrm{~cm}$ of soil depth). Nitrogen fertilization (Ammonium sulphate 20.6\%) was applied at rate of $70 \mathrm{kgs}$ $\mathrm{N} /$ fad. in three equal doses as well as a basal dose of calcium superphosphate (15.5\% $\left.\mathrm{P}_{2} \mathrm{O}_{5}\right)$ and potassium sulphate $\left(48 \% \mathrm{~K}_{2} \mathrm{O}\right)$ at a rate $31 \mathrm{kgs} \mathrm{P}_{2} \mathrm{O}_{5}$ and $48 \mathrm{kgs} \mathrm{K}_{2} \mathrm{O} / \mathrm{fad}$., respectively were soil applied during seedbed preparation. The other agronomic practices were adopted as recommended in the area. Surface irrigation was followed.

A split-split plot design with three replicates was used in both seasons. The three barley cultivars were assigned to the main plots. The sub plots included foliar spray with micro elements (treated and untreated), while farmyard manure treatments were distributed in the sub-sub plots. Plot area was $9 \mathrm{~m}^{2}(3 \times 3)$ including 15 rows 20 $\mathrm{cm}$. part and $3 \mathrm{~m}$. long. The preceding crop was peanut in both seasons. Barley seeds were sown by hand drilling on $20^{\text {th }}$ and $17^{\text {th }}$ of November in the first and second seasons, respectively. Foliar treatment with micro elements (Fertilan 10) at rate $900 \mathrm{~cm}^{3} / \mathrm{fad}$. was sprayed in 600 liter of water after 30, 40, 50 and 60 days from sowing.

At harvest, ten competitive plants were randomly taken from the second inner rows of each plot to determine plant height $(\mathrm{cm})$. In the meantime, 10 spikes were randomly taken to determine spike length (with awn), number of grains/spike and grain weight/spike(g). Also a fixed area of $2 \mathrm{~m}^{2}$ was harvested from each plot to determine number of tillers $/ \mathrm{m}^{2}$, number of spikes $/ \mathrm{m}^{2}, 1000$-grain weight $(\mathrm{g})$, grain yield ton/fad., straw yield ton/fad., biological yield (grain+straw) in ton/fad. and harvest index. Grain protein content was determined as a total nitrogen percentage by micro-Kjeldahle method according to A.O.A.C.(1980), then converted to protein percentage by multiplying 6.25 as used by Tripathi and Kdward (1978).

The results were subjected to standard analysis of variance according to the procedure described by Snedecor and Cochran (1967). For comparison between means, Duncan's multiple range test was used (Duncan, 1955). The combined analysis of variance of the two seasons was used to calculate the simple correlation coefficient as described by Svab (1973).

\section{RESULTS AND DISCUSSION}

\section{1- Varietal differences:}


Highly significant differences were detected among barley cultivars in their, plant height, number of spikes $/ \mathrm{m}^{2}$, spike length, number of grains/spike, grain weight/spike, 1000-grain weight, grain yield, straw yield, protein percentage and biological yield in both seasons and the combined. Also, barley cultivars showed significant differences in numbers of tillers $/ \mathrm{m}^{2}$ during the second season and the combined while these cultivars showed significant differences in harvest index of the $1^{\text {st }}$ season and combined (Tables1, 2 and 3). Relevant results indicated that Giza 124 was superior to the other cultivars in all characters except, protein percentage and harvest index where Giza 125 produced the highest values in this respect. However, the differences did not reach the level of significant between Giza 123 and Giza 125 of number of tillers $/ \mathrm{m}^{2}$, number of spikes $/ \mathrm{m}^{2}$, number of grains/spike, grain weight/spike and grain yield in combined data. Moreover, the differences was not significant between Giza 123 and Giza 124 in harvest index (combined data) . It could be concluded that differences between barley cultivars could be due to genetic differences. These results are in a good line with those reported by El-Kholy and ElBawab, 1998; El-Hindi et al., 1998; Abdel-Hamid and Mohamed, 2000; El-Bawab et al., 2003 and Abd Alla, Maha, 2004.

\section{2- Effect of Fertilan 10 application:}

Foliar spray with Fertilan 10 had significant favourable effects on number of grains/spike, grain weight/spike, 1000-grain weight, grain yield, straw yield and biological yield. This was true in both seasons and in the combined data. Also, foliar nutrition with Fertilan 10 produced significant increase in plant height, number of spikes $/ \mathrm{m}^{2}$ and spike length during the second season and the combined compared with the control. However, significant differences were observed between these treatments in number of tillers $/ \mathrm{m}^{2}$ and harvest index in combined data only. Grain yield/fad. was increased significantly by $16.69 \%$ in the first season, and by $12.77 \%$ in the second one giving average of $14.54 \%$ over the two seasons. These results indicate that Fertilan 10 enhanced the growth processes such as stem and root elongation and leaf expansion (Prasad and Power, 1997 and Trostle et al., 2001). This favourable effect was in turn, reflected in grain and straw yields and almost all of their attributes as observed herein. These results are in accordance with those of Mohmoud et al., 1987, El-Sayed and Abdel-Hadi, 1991 and El-Sayed et al., 1992.

\section{3- Organic manuring effect:}

The data illustrated in Tables 1,2 and 3 indicate clearly that plant height, number of grains/spike, grain weight/spike, 1000-grain weight, grain yield, straw yield and biological yield were increased significantly with increasing rates of Farmyard manure up to $35 \mathrm{~m}^{3} / \mathrm{fad}$. in both seasons and the combined. Also, number of tillers $/ \mathrm{m}^{2}$ and number of spikes $/ \mathrm{m}^{2}$ were increased significantly with increasing 
rate of farmyard manure in the second season and over the two seasons. Furthermore, the differences among the three rates of organic manure were not great enough to reach the level of significance in spike length, protein percentage and harvest index in the two seasons and combined. Also, the differences were not significant between the 35 and $40 \mathrm{~m}^{3}$ farmyard manure rate in number of tillers $/ \mathrm{m}^{2}$, number of spikes $/ \mathrm{m}^{2}$, number of grains/spike, grain weight/spike, 1000-grain weight, grain yield/fad., straw yield/fad. and biological yield in the combined data and most seasons. Application of farmyard manure up to $40 \mathrm{~m}^{3} / \mathrm{fad}$. increased grain and straw yields/fad. significantly by $20.77 \%$ and $34.62 \%$ in the first season, $23.21 \%$ and $32.56 \%$ in the second season and $22.12 \%$ and $33.51 \%$ in the combined compared with $30 \mathrm{~m}^{3}$ rate. The increment in barley yield and its attributes might be attributed to the role of farmyard manure, as a sources of the essential macro and micro nutrients, in enhancing the growth of barley plants as well as dry matter accumulation (Yakout et al., 1998). These results are in agreement with those obtained by Shrma et al.(2001); El-Toukhy and Abd-Alla, (2002) and Kismanyoky ( 2005).

\section{4- Interaction effect:}

The data presented in Tables 1, 2 and 3 show no significant interaction effects between the three factors under study on all regarding studied trait in both seasons and combined. This indicates that the effect of each factor was independent from the effect of the other. Therefore, all cultivars under study showed similar response to spraying micronutrients and addition of farmyard manure.

\section{5- Correlation study:}

The interrelationships between grain yield/fad. and yield contributing characters measured as simple correlation coefficients are shown in Table 4.

Grain yield showed positive and significant correlation with each of plant height, number of tillers $/ \mathrm{m}^{2}$, number of spikes $/ \mathrm{m}^{2}$, spike length, number of grains/spike, weight of grains/spike, 1000-grains weight, straw yield/fad., grain protein content, biological yield and harvest index. Similar results were reported by Sarhan et al.(2002) and Abd Alla, Maha,(2004).

Conclusively, results cleared that the highest yield could be obtained from sowing Giza 124 barely cv. and addition of $35 \mathrm{~m} 3$ FYM with the foliar application of Firtlan 10 , under sandy soil conditions of El-Salhia region, Sharkia Govern orate. 


\section{REFERENCES}

Abd Alla, Maha, M. (2004). Influence of nitrogen level and its application time on yield and quality of some new hull-less barley. J. Agric. Sci. Mansoura Univ., 29 (5): 2201-2216.

Abdel-Hamid, M. and G.A. Mohamed (2000). Effect of nitrogen fertilizer sources and moisture levels on yield and yield components of three barley varieties in middle Egypt. Egypt. J. Appl. Sci., 15 (9): 92-103.

Abdel-Hamid, M. ; G.A. Mohamed and M.M. El-Koliey (2001). Evaluation of different species for biofertilizer and percentage for recommended rate applied nitrogen fertilizer on yield and yield components for some barley varieties. Egypt. J. Appl. Sci., 16 (9): 120-131.

A.O.A.C. (1980). Official Methods of Analysis Association of Official. Agric. Chemists. Washington, D.C.

Berecz, K. ; T. Kismanyoky and K. Dbreczeni (2005). Effect of organic matter recycling in long- term fertilization trials and model pot experiments. Communications in Soil Sci. and Plant Analysis, 36 (113): 191-202.

Duncan, D.B (1955). Multiple range and multiple F-test. Biometrics, 11: 1-24.

El-Bawab, A.M.O. (1999). Yield stability of some newly released barley cultivars in Egypt. Egypt. J. Appl. Sci., 14 (4): 128-136.

El-Bawab, A.M.O. ; M.A.El-Moselhey and M.A. Megahed (2003). Water and fertilizer requirements for barley in sandy soils. Egypt. J. Appl. Sci., 18 (7): 125-133.

El-Hindi, M.H.; A.T.El-Kassaby; A.E.Sharief and K.A.Amer (1998). Yield of barley as affected by different sources and levels of nitrogen fertilization under the environmental conditions of newly reclaimed soils at northern delta of Egypt. Proc. $8^{\text {th }}$ Conf. Agron., Suez Canal, Uni., Ismailia, Egypt, 28-29 Nov., 153-158.

El-Kholy, M.A. and A.M.O. El-Bawab (1998). Response of some barley cultivars to nitrogen fertilization and stimophol as a foliar application. Proc. $8^{\text {th }}$ Conf. Agron., Suez Canal, Univ., Ismailia, Egypt, 28-29 Nov. 145-152.

El-Sayed, A.A. and A.H.Abdel-Hadi (1991). Effect of foliar application of some micronutrients and foliar fertilizers on yield of barley in sandy and calcareous soils. Zagazig J. of Agric. Res., 18 (4): 995-1006.

El-Sayed, A.A. ; M.H.Mahmoud; I.M.Abdel-Aziz and T.A.Mohamed (1992). Response of barley to zinc and the relative contribution of yield attributes in calcareous soils. Zagazig J. Agric. Res., 19 (1): 101-112.

El-Toukhy, S.A. and S.O.M. Abd-Alla (2002). Forage yield and nutritive value of some pasture species intercropped with Acacia saligna under saline 
conditions. Annals of Agric. Sci., Cairo, 47(1): 237-254.

Gomaa, M.M.(1997). Performance of three barley cultivars under varying seeding rates and NPK levels grown on sandy soil. Egypt. J. Appl. Sci., 12 (4): 186-199.

Jha, K.N.; S.V.Ojha and B.D.Singh (1981). Response of barley varieties to levels of nitrogen under rainfed condition. Indian J. Agron., 26,(1): 97.

Kismanyoky, T.(2005). Effect of organic and inorganic fertilization on yield and in long-term field experiments $\mathrm{C}(\mathrm{ORG})$ content of soil. Cereal Res. Communications, 33 (1): 239-242.

Madlain, M. Salib; R.N.Zaki and M.A.Negm (2002). A comparative study on the significance of applied farmyard manure and other affording materials for barley grain on saline soil. Zagazig J. Agric. Res., 29 (4): 1185-1198.

Mahmoud, M.H.; I.M.Abdel-Aziz; A.A.Sayed and M.A.Ashour (1987). Effect of soil and foliar application of zinc on yield components and mineral content of two varieties of barley in different soils. Ann. of Agric. Sci., Fac. Agric., Ain Shams Univ., Cairo, 32 (1): 199-213.

Noaman, M.M.; A.A. El-Sayed; F.A. Asaad; A.M. El-Sherbini; A.O. ElBowab; M.A. El-Moselhi and R.A.Rizk (1995). "Giza 125" and "Giza 126" two barley cultivars for rainfed areas of Egypt. Egypt. J. Apple. Sci., 10 (7): 128-136.

Noworolink, K. and A. Pecio (1989). Effect of nitrogen fertilization on the productivity of new cultivars of winter barley. Pomietnk-Pulawasski (Poland). (1992). (No. 95), 60-82, Distributed.

Prasad, R. and Power (1997). Soil fertilizer Management for Sustainable Agriculture. C.R.C. Press. LLC.

Reuther, W. (1957). Copper and soil fertility. U.S. Dep. Agric. Year Book, pp. 128-134.

Sanjay-Arora and Megh-Singh (2004). Interaction effect of zinc and nitrogen on growth and yield of barley (Hordeum valgare L.) on Typic Ustipsamments. Asian J. of Plant Sci., 3 (1): 101-103.

Sarhan, A.A.; M.A.Megahed and F.A.F.Zahran, (2002). Response of barley to $\mathrm{N}$ and $\mathrm{K}$ fertilization under sandy soil conditions. J. Product \& Dev., 7(1): 19-36.

Sharma, R.P.; V.K. Suri and N.Datt (2001). Integrated nutrient management in summer barley (Hordeum valgare) in a cold desert of Himachal Pradesh. Indian J. of Agric Sci., 71(12): 752-755.

Snedecor, G.W. and W.G.Cochran (1967). "Statistical Methods". the Iowa state Univ., $6^{\text {th }}$ ed, Press. pp: 593, Ames Iowa, U.S.A.

Svab, J. (1973). Biometriai medszerek a kutatasban-Mezogazdasagi. Kiado, Budapest. 
Tripathi, S.K. and J.C. Kdward (1978). Respnse of Rhizobium culture inculation, zinc and molybdenum application of soybean (Glycin max L.). Indian J. Plant Physiology, 21: 248-252.

Trostle, C.L.; P.R. Bloom and D.L. Allah (2001). HEDTA - Nitrilotriacetic acid chelator-buffered nutrient solution for zinc deficiency evaluation in rice. Soil Sci. Soc. Am. J., 65: 385-390.

Yakout, G.M.; M.H. Greish and R.A. Ata-Alla (1998). Response of wheat crop to seeding rates, nitrogen fertilizer and organic manure under new reclaimed soil conditions. Proc. $8^{\text {th }}$ Conf. Agron., Suez Canal Univ., Ismailia, Egypt, 28-29 Nov.

استجابة بعض أصناف الثعير للسماد العضوى والتغذية الورقية بمركب العناصر الصغرى فرتيلان ا تحت ظروف الأرض الرملية حديثة الاستصلاح

"السبد بيومي جاب الله و **صابر عبد الحميد السبد موافي

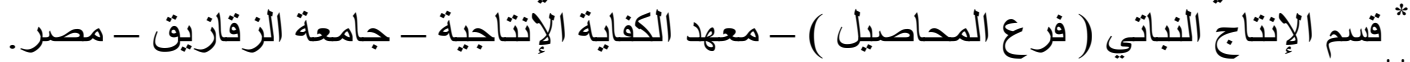

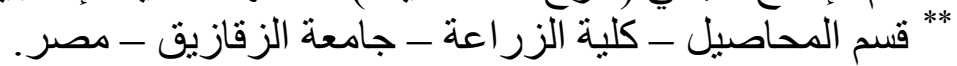

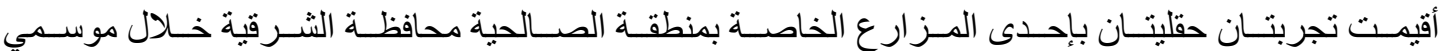

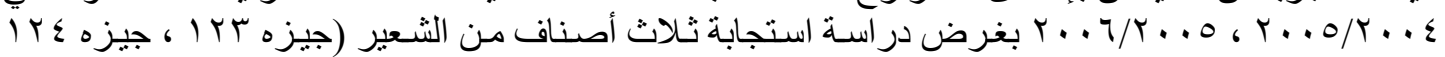

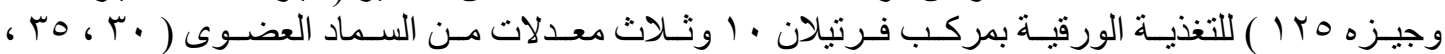

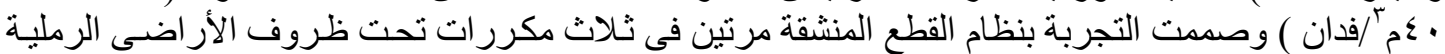
حديثة الاستصلاح وتتلخص أهم النتائج فيما يلى :

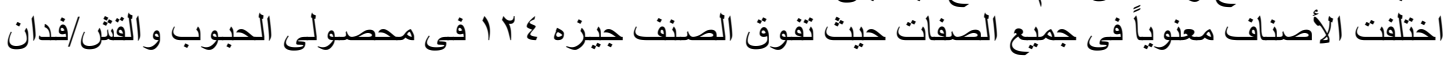

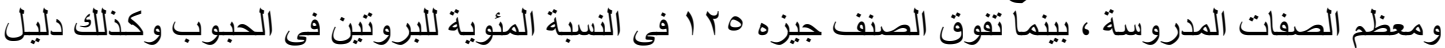

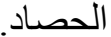
أدت التغذية بمركب فرتيلان • ( إلى تحسين معظم الصفات المدروسة وحققت زيادة معنوية فى محصول الفدان

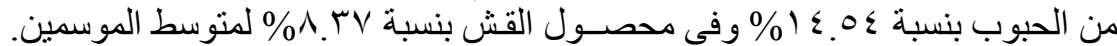

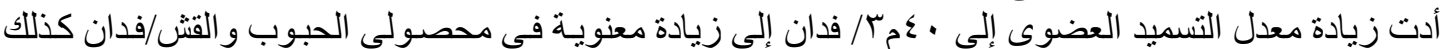

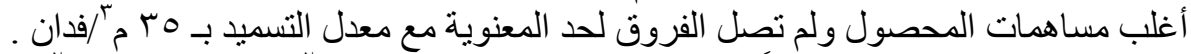

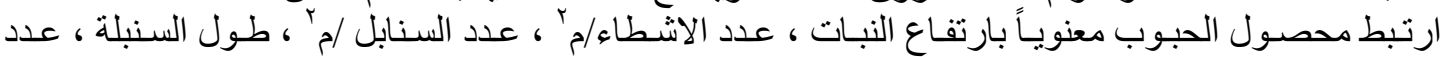

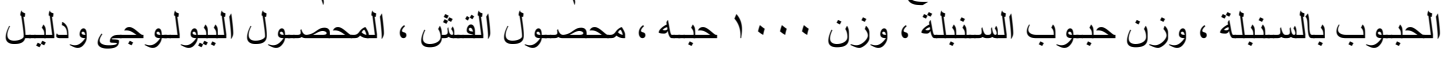

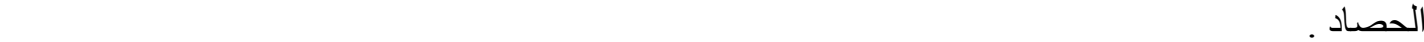

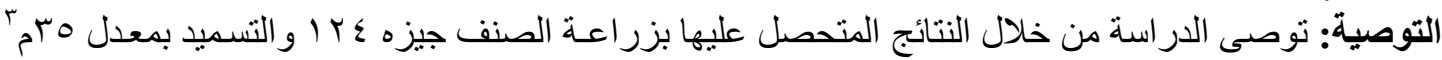

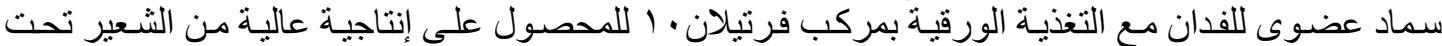

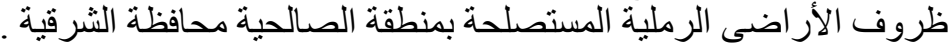

